Pollock AM, Roderick P. Why we should be concerned about accountable care organisations in England's NHS. BMJ 2018, 30: k343.

DOI link

https://doi.org/10.1136/bmj.k343

ePrints link

http://eprint.ncl.ac.uk/pub details2.aspx?pub id=245584

Date deposited

$06 / 02 / 2018$

Copyright

For personal use only: See rights and reprints http://www.bmj.com/permissions 


\title{
Why we should be concerned about accountable care organisations in England's NHS
}

The government and NHS England's plans for a major reorganisation of the health and adult social care system must come under greater scrutiny, argue Allyson Pollock and Peter Roderick

\author{
Allyson M Pollock professor of public health, Peter Roderick principal research associate \\ Institute of Health and Society, Newcastle University, Newcastle upon Tyne, UK
}

The introduction of accountable care organisations (ACOs) into the English NHS signals a major reorganisation of the health and adult social care system. Plans for ACOs were proceeding without the usual public consultation followed by an act of parliament. However, after the launch of a judicial review (in which AMP is a claimant and PR is assisting the claimants), the government and NHS England have now announced there will be a national public consultation in the spring. ${ }^{1}$ Consultation and legislation are necessary safeguards to ensure that the plans are consistent with the fundamental principles of the NHS of a universal and comprehensive service that is publicly funded, accountable, and free at the point of delivery.

The term ACO (accountable care organisation) emerged in the US in 2006, ${ }^{2}$ and became a central feature of President Obama's health reforms. ${ }^{3}$ In the United States, ACOs consist of groups of doctors, hospitals, and other providers who are given incentives to improve quality of care and control costs. Providers within the ACO are entitled to a share of any "savings" to the public budget that are achieved. ${ }^{4}$

ACOs were designed to improve patient experience and control federal expenditure within the US healthcare system, which is dominated by private health and insurance companies. So far the evidence of the effect of ACOs on quality is contested, and at best mixed. ${ }^{5}$ The projected savings to federal budgets translated into a net loss in 2015, and spending may have actually increased.

The US insurance based healthcare system is fundamentally different from the NHS, not least in that it does not seek to provide universal care, giving rise to several questions and uncertainties about how the ACO model will apply in the NHS.

\section{ACOs in the NHS}

Sustainability and transformation partnerships seem to be the forerunner for ACOs in England, ${ }^{7}$ but it is unclear how closely the introduction and expansion of ACOs in England will reflect the model that has evolved in the US.

We base the following analysis on NHS England's draft ACO contract published in August 2017 and its associated policy documents, although these might now change as a result of the recently announced consultation. According to NHS England, the "ACO model simplifies governance and decision making, brings together funding streams and allows a single provider organisation to make most decisions about how to allocate resources and design care for its local population." ${ }^{8}$

The draft ACO contract is intended to facilitate the use of two new models of care-fully or partially integrated "multispecialty community providers" and "primary and acute care systems." In the fully integrated model, the ACO will have "full responsibility for provision and integration of care" ${ }^{\text {" for up to }}$ 15 years. ${ }^{10}$

\section{How will ACOs be funded?}

The government's intention is to move to a capitation system (lump sum per patient) with a linked outcomes and incentives payment scheme. The list based capitation payments made to the ACO will be derived from current commissioner expenditure on services. ${ }^{11}$ The complexity in deriving risk adjusted capitation is enormous and well known. ${ }^{12}$ Personal health budgets are also being proposed. We are concerned that these changes will further undermine risk pooling, social solidarity, and equity, which are required for universality, for reasons outlined in Boxed Text on page 2 box $1 .^{15}$ 


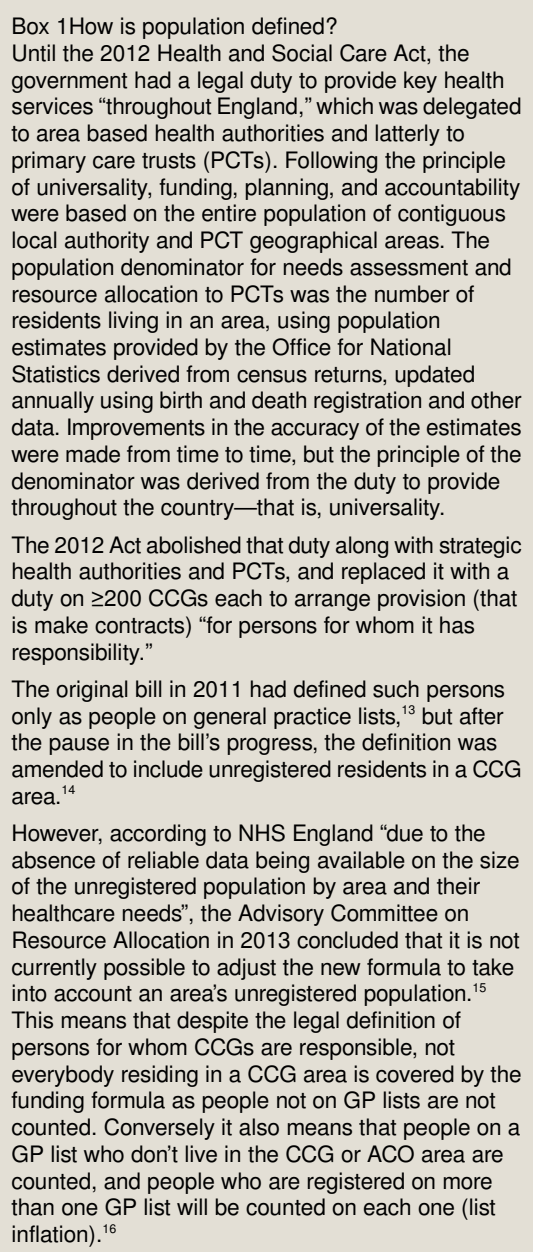

It is unknown how ACOs can integrate health and social care services when their funding will be for a different population (GP lists versus local authority), and when ACOs will not have health service funding allocated for unregistered CCG residents who may be eligible under the ACO contract for local authority social services.

\section{What do we know about the ACO contract?}

Under the draft ACO contract was published in August 2017 a group of clinical commissioning groups, NHS England, and local authorities would pool their health, public health, and adult social care commissioning budgets and transfer them to the $\mathrm{ACO}$ in return for the ACO providing or subcontracting defined "services" to "the population." However, social services are means tested and charged for, while health services are not $^{17}$-how pooling these budgets would work in practice is unclear.

The transfer of risk and responsibility for funding, commissioning, and providing health and social services to ACOs raises several concerns, the most serious of which we discuss below.

\section{Who would be entitled to receive what services?}

Entitlement to services seems to depend on whether an individual falls within the definition of "the population." To meet this definition an individual must either be registered on the ACO's list or be permanently (or temporarily) resident in the "contract area" and not on the list of a GP who's not part of the ACO (Boxed Text on page 2box 1).

There is much uncertainty about what ACOs will provide and to which populations. The definition of "services" is complex and unclear and seems to involve finding a negotiated compromise between the services required by the commissioners and those proposed by the ACO.

This could lead to confusion if, for example, an individual lived in the contract area and required health and social services but was not on the ACO's list because their general practice was a member of a CCG which contracts with another ACO.

\section{Public involvement and accountability}

Transferring billions of pounds to non-statutory providers raises important accountability issues, and there are several ways in which public involvement in and accountability for ACO decisions on services would be degraded, compared with the current position.

ACOs would not have statutory obligations, and public involvement would depend on the terms of the ACO contract. These terms are enforceable by parties to the contract, not by members of the public. Under the NHS standard contract, providers must involve "service users" and "the public" (among others) when developing and redesigning services. Under the ACO contract, ACOs would be required only to involve "the population." This raises the question of how the public would be consulted when service changes are planned through the contract, especially when neither ACOs nor CCGs have geographical populations, when GP and hence ACO lists may include people from anywhere, and when ACOs will not be funded to cover unregistered patients.

We do not know whether individual ACOs could be subject to judicial review, or to a human rights or freedom of information challenge-key mechanisms for holding public bodies to account. Outsourcing of public services to private and voluntary bodies has led to several cases where the courts have had to wrestle with where and how to draw the line between publicly accountable and private bodies. ${ }^{18}{ }^{19}$ In 2007 , for example, the House of Lords held that private care homes funded through local authority contracts were not exercising functions of a public nature under the Human Rights Act $1998,{ }^{20}$ and this had to be reversed seven years later by the Care Act.

\section{Assessment of needs}

Assessing needs is the first stage of the commissioning function, ${ }^{21}$ conferred on NHS England and CCGs under sections 3 and 3A of the Health and Social Care Act 2012. It is a core task of commissioners, with local people and communities supposed to be engaged throughout. ${ }^{22} 23$ An ACO would be obliged to "develop and implement strategies to improve the health and wellbeing of the population" and to "maintain a documented, current and thorough assessment of the health [and social] care needs of the population." ${ }^{24}$ This means that statutory duties would be transferred to the ACO, distancing democratically elected representatives and the public from the decision making.

\section{How have ACOs been justified?}

In February 2017, NHS England's head, Simon Stevens, when giving evidence to the Public Accounts Committee, said that "accountable care organisations or systems... will for the first time since 1990 effectively end the purchaser-provider split, 
bringing about integrated funding and delivery for a given geographical population." 25

The purchaser-provider split is established in primary legislation so it is unclear how ACOs will end it. Implementation of the split-introduced by the NHS and Community Care Act 1990 — was completed by the 2012 Act with the abolition of the health secretary's "duty to provide" and of primary care trusts (see Boxed Text on page 2box 1). ${ }^{26}$

Plans suggest that commissioning for health and social care services would be handed over to ACOs for 10 or more years, with no basis for geographical planning. They would be in charge of allocating resources and designing care, allowed to make contracts for all of the services, and not be obliged to provide any. In other words, ACOs would become commissioners.

Integration of health and care services has long been an aim. Parliament legislated for it in $1999,{ }^{27}$ re-enacted in 2006. We believe that this integration can be achieved only through legislation to resolve the different funding and population bases of local authorities, primary care, CCGs, and NHS England, to reinstate the duty to provide throughout England and the geographical basis for universal healthcare. However, the contracting associated with an ACO model is likely to lead to further fragmentation and loss of public control and public accountability. In the absence of the government's duty to provide throughout England, we believe this will leave wide open the possibility of groups of people and services being excluded from NHS services, as providers seek to find ways to reduce their financial risks and maximise their gains. As well as loss of universal coverage, we expect that everyone will be required to produce proof of entitlement.

\section{Has there been sufficient public consultation and due parliamentary process?}

We are deeply concerned that a plan for national consultation on this major reorganisation of the health and adult social care system has been promised only after the launch of a judicial review and that there is no plan for a new health act. Stevens has said that "we can do workarounds" of the current legislation and "we will...push as hard as we can to get there without Parliament itself having to legislate." ${ }^{28}$ Previous changes of this magnitude have all been preceded by a process of public consultation and acts of parliament $(\Downarrow)$. The consultation that has now been announced may help to allay the concerns about the ACO contract, but the absence of primary legislation remains worrying.

ACOs will be non-statutory, non-NHS bodies-even when formed by or including NHS trusts or foundation trusts. They will receive billions of pounds of public money but have no statutory accountability or governance obligations. Their form and ownership would be unrestricted ${ }^{29}$ and could therefore include not only general practitioners and private companies but also insurers, banks, or property companies (see infographic). They can be established as off-shore companies. The ACO would need a raft of contracts with trusts, general practices, private health companies, and voluntary organisations to provide services. This will lead to further fragmentation and bureaucracy, loss of public control, and unnecessary expenditure. The Department of Health has consulted on technical changes to regulations in order to facilitate ACOs going live from April $2018 .^{30}$ The changes, depending on the model type, would allow general practices to give one month's notice to NHS England of their wish to suspend their current contracts and instead to provide services under an ACO contract; patients must have been given notice of the practice's wish, and they will automatically be transferred to the ACO's list of registered patients, unless they register with another practice. The secretary of state has refused to delay the regulations, despite being repeatedly asked by Sarah Wollaston, chair of the Health Select Committee, in an evidence session on 23 January $2018 .^{31}$

The lack of clarity surrounding ACOs hampers a full appreciation of the nature and scale of these changes. We have highlighted some of the most important problems. Legal action was begun on the grounds that without an act of parliament the plans are unlawful; there should be proper public consultation; and the principles which provide that decisions about our NHS should be clear and transparent have been breached. ${ }^{32}$ The government and NHS England have conceded now that there will be a national consultation, but that does not necessarily mean that the policy will be reversed.

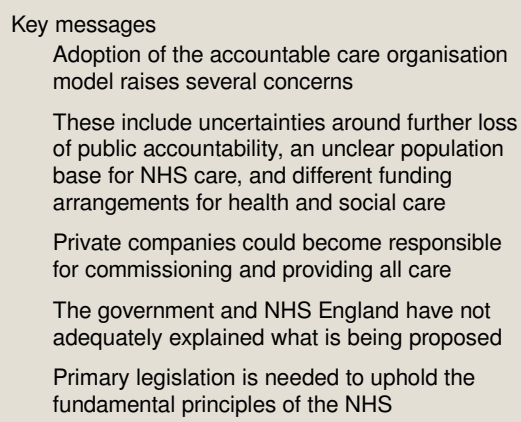

Contributors and sources: AMP is an academic public health expert with extensive experience and expertise over many years in local authority and health authority planning and needs assessment, and the private finance initiative. PR has extensive legal experience and expertise over 35 years. Together they have researched and written extensively on the Health and Social Care Act 2012, during its passage through parliament and since, and are coauthors of the proposed NHS Reinstatement Bill. The article arose out of their study of the draft ACO contract and the consultation on the proposed regulations mentioned in the text. They jointly developed the ideas, carried out research, and wrote and edited the article.

Competing interests We have read and understood BMJ policy on declaration of interests and declare the following interests: AMP is one of five claimants seeking a judicial review of the secretary of state for health's and NHS England's ACO plans. PR has assisted the claimants. The authors are grateful to Graham Winyard, also a claimant in the judicial review, for his assistance in compiling the table.

Provenance and peer review: Not commissioned; externally peer reviewed.

lacobucci G. Government postpones first ACOs to allow further consultation. BMJ 2018;360:k412.

2 Fisher ES, Staiger DO, Bynum JPW, Gottlieb DJ. Creating accountable care organizations: the extended hospital medical staff. Health Aff (Millwood) 2007;26:w44-57. doi:10.1377/hlthaff.26.1.w44.17148490

3 The Patient Protection and Affordable Care Act 2010, section 3022. https://www.gpo.gov/ fdsys/pkg/PLAW-111 publ148/pdt/PLAW-111publ148.pdf

4 Centers for Medicare \& Medicaid Services. Accountable care organizations. https://www cms.gov/Medicare/Medicare-Fee-for-Service-Payment/ACO/index.html

5 Erwin A, Blackstone EA, Fuhr JP. Jr. The economics of Medicare accountable care organizations. Am Health Drug Benefits 2016;9:11-9.

6 Douven R, McGuire TG, McWilliams JM. Avoiding unintended incentives in ACO payment models. Health Aff (Millwood) 2015;34:143-9. doi.org/10.1377/hlthaff.2014.0444. doi:10.1377/hlthaff.2014.044425561655

7 Moberly T. Accountable care systems and accountable care organisations. BMJ 2017;358:j4105. doi:10.1136/bmj.j4105.28871038 
8 NHS England. Integrating care: contracting for accountable care models. Paragraph 5. 2017. https://www.england.nhs.uk/wp-content/uploads/2016/12/1693_DraftMCP-1a_A. pdf

9 NHS England. Integrating care: contracting for accountable care models. Paragraph 16 2017. https://www.england.nhs.uk/wp-content/uploads/2016/12/1693_DraftMCP-1a_A pdf

10 UK Government. Contracts finder. Multi-specialty community provider (MCP)—Dudley. NHS Arden and Greater East Midlands. https://www.contractsfinder.service.gov.uk/Notice/ 8840a0a4-d576-43ff-935f-4e1488073290?p=@RRPT0=NjJNT08=UFQxUI

11 NHS England. Whole population models of provision: Establishing integrated budgets. 2017. https://www.england.nhs.uk/wp-content/uploads/2017/08/1693_DraftMCP-7b_A pdf

12 Gifford GA, Edwards KR, Knutson DJ. Health-based capitation risk adjustment in Minnesota public health care programs. Health Care Financ Rev 2004;26:21-41. https://www.ncbi. nlm.nih.gov/pmc/articles/PMC4194869/.25372356

13 UK Parliament. Bill documents - Health and Social Care Act 2012. https://services. parliament.uk/bills/2010-12/healthandsocialcare/documents.html

14 Health and Social Care Bill. (HC Bill 221). https://publications.parliament.uk/pa/bills/cbill/ 2010-2012/0221/cbill_2010-20120221_en_1.htm

15 NHS England. Technical guide to allocation formulae and pace of change for 2016-17 to 2020-21 revenue allocations to clinical commissioning groups and commissioning areas. 2016. https://www.england.nhs.uk/wp-content/uploads/2016/04/1-allctins-16-17-tech-guidformulae.pdf

16 NHS England. Tackling list inflation for primary medical services. 2013. https://www. england.nhs.uk/wp-content/uploads/2013/10/tack-infla.pdf

17 Sutaria S, Roderick P, Pollock AM. Are radical changes to health and social care paving the way for fewer services and new user charges? BMJ 2017;358:14279. doi:10.1136/bmj.j4279.28954738

18 Hampshire County Council v Graham Beer (t/a Hammer Trout Farm) [2003] EWCA Civ 1056. http://www.bailii.org/ew/cases/EWCA/Civ/2003/1056.html

19 Holmcroft Properties Ltd. R (on the application of) v KPMG LLP \& Ors [2016] EWHC 323 (Admin).http://www.bailii.org/ew/cases/EWHC/Admin/2016/323.html

$20 \mathrm{YL}$ (by her litigation friend the Official Solicitor) (FC) (Appellant) v. Birmingham City Counci and others (Respondents) [2007] UKHL 27. http://www.bailii.org/uk/cases/UKHL/2007/ 27.html
21 NHS. The commissioning handbook for librarians. The commissioning cycle.: http:// commissioning.libraryservices.nhs.uk/commissioning-cycle

22 RCGP. Principles of commissioning. www.rcgp.org.uk/revalidation-and-cpd/ /media 6C164D7796EA49A3AC25AD5383AEC653.ashx

23 UK Government. Statutory guidance on joint strategic needs assessments and joint health and wellbeing strategies. 2012, https://www.gov.uk/government/uploads/system/uploads/ attachment_data/file/223842/Statutory-Guidance-on-Joint-Strategic-Needs-Assessmentsand-Joint-Health-and-Wellbeing-Strategies-March-2013.pdf

24 NHS England. Draft NHS standard contract (accountable care models) 2017/18 and 2018/19, draft service conditions, service condition 3.2. https://www.england.nhs.uk/wpcontent/uploads/2017/08/1bii.-170804-ACO-Contract-Service-Conditions.pdf

25 House of Commons Public Accounts Committee. Oral evidence: integrated health and social care, HC 959, 27 Feb 2017. Q93. http://data.parliament.uk/writtenevidence/ committeeevidence.svc/evidencedocument/public-accounts-committee/integrated-healthand-social-care/oral/48009.html

26 Health and Social Care Act 2012. Explanatory notes, paragraph 71. http://www.legislation. gov.uk/ukpga/2012/7/notes/division/5/1/1

27 Health Act 1999. Explanatory notes, paragraph 231. http://www.legislation.gov.uk/ukpga/ 1999/8/notes/division/5/1/28

28 House of Commons Public Accounts Committee. Oral evidence: Integrated Health and Social Care, HC 959, 27 Feb 2017: Q112 and Q118. http://data.parliament.uk writtenevidence/committeeevidence.svc/evidencedocument/public-accounts-committee/ integrated-health-and-social-care/oral/48009.html

29 Lucas C. Written question-105277. Health services: contracts. House of Commons Hansard 14 Sep 2017. http://www.parliament.uk/business/publications/written-questionsanswers-statements/written-question/Commons/2017-09-14/105277

30 Department of Health. Accountable care models contract: proposed changes to regulations, 11 Sep-5 Nov 2017. https://www.gov.uk/government/consultations/accountable-caremodels-contract-proposed-changes-to-regulations

31 Health committee 23 Jan 2018. http://www.parliamentlive.tv/Event/Index/70452f3d-4f8b4db0-9177-fd8e7fda9343

32 Urgent legal action for our NHS. https://www.crowdjustice.com/case/jr4nhs-round2/

Published by the BMJ Publishing Group Limited. For permission to use (where not already granted under a licence) please go to http://group.bmj.com/group/rights-licensing/ permissions 


\section{Table}

\section{Table 1| Acts of parliament, consultations, and reforms of the NHS, 1946-2012}

\begin{tabular}{|c|c|c|}
\hline Act & Consultation & Main reforms \\
\hline NHS Act 1946 & $\begin{array}{l}\text { The Beveridge Report (1942); A National Health Service, } \\
\text { white paper (1944) }\end{array}$ & Established the NHS in England and Wales \\
\hline NHS Reorganisation Act 1973 & $\begin{array}{l}\text { The administrative structure of the medical and related } \\
\text { services in England and Wales, green paper } 1 \text { (1968); } \\
\text { The future structure of the NHS in England, green paper } \\
\text { 2; NHS reorganization, consultation document (1971). }\end{array}$ & $\begin{array}{l}\text { Integrated GP, hospital, and community services under unitary health } \\
\text { authorities; transferred public health and community services from local } \\
\text { authorities; created regional health authorities }\end{array}$ \\
\hline Health Services Act 1980 & Patients First, consultation document (1979) & Simplified over-complex management system \\
\hline $\begin{array}{l}\text { NHS and Community Care Act } \\
1990\end{array}$ & Working for Patients, white paper (1989) & $\begin{array}{l}\text { Established NHS trusts and introduced internal market with health } \\
\text { authorities and GP fundholders "purchasing" services from hospital and } \\
\text { community "providers" }\end{array}$ \\
\hline Health Authorities Act 1995 & $\begin{array}{l}\text { Functions and Manpower Review (1993); Managing the } \\
\text { new NHS: proposal to determine the new NHS regions } \\
\text { and establish new Regional Health Authorities, } \\
\text { consultation document (1993) }\end{array}$ & $\begin{array}{l}\text { Merged district and family health service authorities to form health } \\
\text { authorities; replaced regional health authorities by regional offices of the } \\
\text { Department of Health }\end{array}$ \\
\hline $\begin{array}{l}\text { Health Act 1999, NHS Reform } \\
\text { and Health Care Professions Act } \\
\text { 2002, Health and Social Care } \\
\text { (Community Health and } \\
\text { Standards) Act } 2003\end{array}$ & $\begin{array}{l}\text { The New NHS: Modern and Dependable, white paper } \\
\text { (1997); A First Class Service, consultation document on } \\
\text { quality in the new NHS (1998); The NHS Plan: a plan for } \\
\text { investment, a plan for reform (2000); Shifting the balance } \\
\text { of power within the NHS: Securing delivery (2001) }\end{array}$ & $\begin{array}{l}\text { GP fundholding abolished; primary care trusts established as principal } \\
\text { commissioners of primary and secondary care. } 95 \text { health authorities } \\
\text { replaced by } 28 \text { strategic health authorities. Regional offices of DH } \\
\text { abolished. Foundation trusts, their independent regulator, the National } \\
\text { Institute for Clinical Excellence (NICE), and the Commission for Health } \\
\text { Improvement established }\end{array}$ \\
\hline NHS Act 2006 & $\begin{array}{l}\text { Commissioning a patient-led NHS, Department of Health } \\
\text { (2005) }\end{array}$ & $\begin{array}{l}28 \text { strategic health authorities reduced to } 10 \text { to be coterminous with } \\
\text { regional government offices. } 303 \text { primary care trusts reduced to } 152\end{array}$ \\
\hline \multirow[t]{6}{*}{ Health and Social Care Act 2012} & $\begin{array}{l}\text { Equity and Excellence: liberating the NHS, white paper } \\
\text { (2010) }\end{array}$ & $\begin{array}{l}\text { Government's duty to provide abolished. Strategic health authorities and } \\
\text { primary care trusts abolished }\end{array}$ \\
\hline & & NHS England and clinical commissioning groups established \\
\hline & & Transfer of many NHS public health functions back to local authorities. \\
\hline & & All NHS trusts prospectively abolished \\
\hline & & $\begin{array}{l}\text { NHS foundation trusts allowed to earn } 49 \% \text { of their income outsider the } \\
\text { NHS }\end{array}$ \\
\hline & & $\begin{array}{l}\text { Provider licensing system established under the regulator, re-named } \\
\text { Monitor, with new competition and regulatory powers }\end{array}$ \\
\hline
\end{tabular}

